\title{
Peningkatan Penguasaan Vocabulary Teks Deskriptif melalui Pendekatan Scientific dengan Model Guide Inquiry pada Siswa SMPN 1 Besuki
}

\author{
Ida Nurhayati ${ }^{1}$ \\ ${ }^{1}$ SMPN 1 Besuki, Tulungagung \\ Email: ${ }^{1}$ idanurhayati@gmail.com
}

\begin{tabular}{l} 
Tersedia Online di \\
\hline http://www.jurnal.unublitar.ac.id/ \\
index.php/briliant \\
\hline \\
\hline Sejarah Artikel \\
\hline Diterima pada 11 Februari 2018 \\
Disetuji pada 11 Februari 2018 \\
Dipublikasikan pada 13 Februari \\
2018 Hal. $70-79$
\end{tabular}

\section{Kata Kunci:}

vocabulary teks deskriptif,

pendekata scientific, guide inquiry

\section{DOI:}

http://dx.doi.org/10.28926/briliant .v3i1.142

\begin{abstract}
Abstrak: Berdasarkan hasil observasi yang dilakukan di Kelas VIII B pada waktu pembelajaran Bahasa Inggris diperoleh hasil bahwa Prestasi belajar siswa kurang memuaskan, yaitu dari 26 siswa hanya 1 siswa yang nilainya dapat mencapai $\mathrm{KKM}$ atau $\geq 70$ dan 10 siswa nilainya antara 41-69, sedangkan 15 siswa lainnya nilainya $\leq 41$. Untuk itu agar dapat meningkatkan Prestasi belajar siswa dalam menyelesaikan soal tentang Vocabulary Teks Descritive serta untuk tercapainya tujuan pembelajaran perlu diadakan perbaikan pembelajaran dengan menerapkan Metode Pendekatan Scientific dengan Model Guide Inquiry. penerapan pembelajaran Vocabulary Teks Descritive melalui Metode Pendekatan Scientific dengan Model Guide Inquiry dapat meningkatkan Prestasi belajar siswa Kelas VIII B SMP Negeri 1 Besuki Tulungagung dan dapat mempermudah siswa dalam menyelesaikan persoalan Vocabulary Teks Descritive.
\end{abstract}

Kurikulum Departemen Pendidikan Nasional, khususnya pada mata pelajaran bahasa Inggris menetapkan bahwa kemampuan yang harus dimiliki oleh siswa Indonesia adalah memahami dan mengungkapkan informasi, pikiran, perasaan, serta mengembangkan ilmu pengetahuan, teknologi, dan budaya dengan menggunakan bahasa Inggris. Dengan demikian, fungsi bahasa Inggris sebagai alat untuk berkomunikasi diupayakan dalam rangka mengakses informasi untuk membina hubungan interpersonal, bertukar informasi serta menikmati estetika bahasa dalam budaya Inggris. Oleh karena itu, mata pelajaran Bahasa Inggris di sekolah secara umum memiliki tujuan sebagai berikut: (1) Mengembangkan kemampuan berkomunikasi dalam bahasa Inggris, baik dalam bentuk lisan atau tulis, yang meliputi kemampuan mendengarkan (listening), berbicara (speaking), membaca (reading), dan menulis (writing). 2) Menumbuhkan kesadaran tentang hakikat bahasa dan pentingnya bahasa Inggris sebagai salah satu bahasa asing untuk menjadi alat utama belajar. 3) Mengembangkan pemahaman tentang saling keterkaitan antarbahasa dan budaya serta memperluas cakrawala budaya agar siswa memiliki wawasan lintas budaya dan dapat melibatkan diri dalam keragaman budaya.

Keempat keterampilan tersebut akan dapat tercapai dengan baik apabila siswa memiliki kemampuan kosa kata (vocabulary) yang memadai. Vocabulary merupakan salah satu komponen penting dalam pengajaran bahasa Inggris di samping komponen lainnya seperti structure, pronunciation dan intonation. Vocabulary mempunyai peranan yang sangat vital. Jika seorang siswa lemah dalam penguasaan vocubalary, maka tidak dapat meng-komunikasikan pikiran dan 
idenya dengan jelas seperti yang diinginkannya baik lisan maupun tulisan. Siswa tidak dapat mengutarakan dengan sempurna apa yang ingin ia sampaikan saat dia berbicara atau menjelaskan apa yang dia inginkan. Siswa tidak akan mampu membaca text baik yang merupakan bahan ajar disekolah maupun yang ada pada majalah, surat kabar dan sebagainya. Bahkan siswa tidak dapat memahami siaran yang dipancarkan melalui radio maupun televisi. Demikan juga kemampuan dalam menyimak dan membaca akan terkendala dengan penguasaan kosakata yang terbatas. Sudah merupakan pendapat umum, memiliki kosakata yang memadai merupakan modal untuk lancarnya berkomunikasi.

Lebih lanjut Jeremy Harmer (1991) menganalogkan jika bahasa itu merupakan sebatang tubuh, structure merupakan tulang yang membentuk rangka sedangkan kosakata atau vocabulary merupakan daging yang membuat tubuh mempunyai bentuk. Dengan demikian seorang tidak akan dapat berkomunikasi dalam bahasa sasaran kalau penguasaan kosakatanya tidak memadai.

Dari uraian di atas dapat disimpulkan, ketidakmampuan sebagian besar siswa SMP untuk berkomunikasi dalam bahasa Inggris salah satu factor adalah disebabkan kurangnya penguasaan kosakata. Penguasaan kosa kata merupakan hal yang paling mendasar yang harus dikuasai seseorang dalam pembelajaran bahasa inggris yang merupakan bahasa asing bagi seluruh siswa dan masyarakat Indonesia.

Bagaimana seseorang dapat mengungkapkan suatu bahasa apabila ia tidak memahami kosakata dari bahasa tersebut. Apalagi kalau yang dipelajari itu adalah bahasa asing, sehingga penguasaan kosakata bahasa tersebut merupakan sesuatu yang mutlak dimiliki oleh pembelajar bahasa. Apabila seorang siswa memiliki perbendaharaan kata bahasa inggris yang memadai maka otomatis akan lebih menunjang pada pencapaian empat kompetensi bahasa inggris tadi. Demikian juga sebaliknya tanpa memiliki kosa kata yang memadai seorang siswa akan mengalami kesulitan dalam mencapai kompetensi berbahasa di atas. Dengan demikian dapatlah dikatakan bahwa dengan penguasaan kosa kata yang memadai diharapkan siswa akan lebih mudah dan mampu mengaplikasikannya dalam kalimat, khususnya dalam Bahasa Inggris, berbentuk Descriptive text.

Dalam pelaksanaan proses pembelajaran bahasa inggris, penulis sering mendapati para siswa di SMP Negeri 1 Besuki Tulungagung, sekolah tempat penulis mengajar mengalami kesulitan dalam mencapai suatu kompetensi dasar. Hal ini dikarenakan penguasaan kosakata bahasa Inggris siswa kurang memadai, sehingga sangat mengganggu pencapaian kompetensi seperti yang tertera dalam kurikulum. Mereka sering kesulitan memahami arti sebuah kata karena pemahaman kosakata mereka relatif kurang memadai sehingga proses pencapaian suatu kompetensi dasar akan berjalan lebih lama.

Apabila para siswa mengalami kesulitan dalam memahami arti sebuah kata selama proses pembelajaran maka dengan terpaksa akhirnya penulis memberikan jalan pintas pada mereka dengan cara menyuruh siswa mencari arti kata tersebut dalam kamus dan memberitahu secara langsung arti dari kata tersebut. Walaupun cara tersebut apabila terlalu sering digunakan berakibat kurang baik bagi para siswa karena hanya beberapa orang siswa yang memiliki kamus dan siswa menjadi tergantung pada kamus bukan pada pemahaman konteks kata, serta siswa sering menunggu pada makna kata yang berasal dari guru 
Berdasarkan hasil pengamatan dalam proses belajar mengajar dikelas, keadaan sekolah, dan melalui peninjauan bidang akademik dan non akademik, diperoleh hasil bahwa keadaan SMP Negeri 1 Besuki Tulungagung khususnya siswa Kelas VIII B tahun ajaran 2015/2016 dalam pelajaran Bahasa Inggris belum menunjukkan prestasi belajar sesuai dengan KKM yang ditetapkan terutama pada pengerjaan Vocabulary teks descritive. Padahal, ditinjau dari keadaan fisik sekolah, yaitu ruang Kelas VIII B sudah baik dan sesuai sebagai tempat berlangsungnya proses belajar mengajar. Pengamatan pada proses pembelajaran oleh peneliti dapat disimpulkan bahwa pelaksanaan proses belajar mengajar lah yang belum membuat siswa aktif belajar, sehingga kemampuan siswa belum tergali dengan maksimal.

Pada ulangan harian Bahasa Inggris dengan Vocabulary teks descritive, di dapat rata-rata nilai sebesar 54,4 dari 26 siswa, padahal Kriteria Ketuntasan Minimalnya (KKM) telah ditentukan nilai sebesar 70. Di dapati hanya 1 siswa yang mendapat nilai di atas 70 dan 10 siswa mendapat nilai antara 41-69. Hal ini berarti, hanya $3,85 \%$ dari siswa yang telah mencapai ketuntasan belajar, dan yang lainnya memiliki prestasi belajar yang rendah.

Oleh karena itu, demi memperbaiki berbagai masalah yang ada, peneliti memerlukan suatu solusi untuk mengatasi hambatan-hambatan yang terjadi. Akhirnya diputuskan dengan menggunakan Pendekatan scientific dengan model Guide inquiry dalam pembelajaran Bahasa Inggris ini. Pendekatan yang digunakan dalam pembelajaran yaitu pendekatan ilmiah (Scientific Approach). Pendekatan ini lebih efektif hasilnya jika diimplementasikan di dalam kelas dibandingkan dengan pendekatan tradisional, yaitu meningkatnya kemampuan siswa dari aspek pengetahuan (kognitif), sikap (afektif), dan keterampilan (psikomotor). Pendekatan scientific dengan model Guide inquiry adalah metode pembelajaran yang menempatkan siswa bertanggungjawab secara penuh terhadap proses belajarnya, dan Guru hanya memberikan bimbingan terbatas pada pemilihan topik dan pengembangan pertanyaan.

Muslimin Ibrahim (2007: 1), mendefinisikan inquiry sebagai suatu proses untuk memperoleh dan mendapatkan informasi dengan melakukan observasi dan atau eksperimen untuk mencari jawaban atau memecahkan masalah terhadap pertanyaan atau rumusan masalah dengan menggunakan kemampuan berpikir kritis dan logis.

Secara umum, inquiry merupakan proses yang bervariasi dan meliputi kegiatan-kegiatan mengobservasi, merumuskan pertanyaan yang relevan, mengevaluasi buku dan sumber-sumber informasi lain secara kritis, merencanakan penyelidikan atau investigasi, mereview apa yang telah diketahui, melaksanakan percobaan atau eksperimen dengan menggunakan alat untuk memperoleh data, menganalisis dan menginterpretasi data, serta membuat prediksi dan mengkomunikasikan hasilnya.

Pendekatan scientific dengan model Guide inquiry dalam pembelajaran adalah mengembangkan kemampuan berpikir secara sistematis, logis dan kritis atau mngembangkan kemampuan intelektual sebagai bagian dari proses mental. Kegiatan guide inquiry sangat penting karena dapat mengoptimalkan keterlibatan pengalaman langsung siswa dalam proses pembelajaran. Joyce, et al (Muslimin Ibrahim, 2007: 5) menyatakan bahwa guide inquiry perlu didesain untuk membelajarkan proses penelitian yang dapat mempengaruhi cara siswa 
memproses informasi dan mengembangkan komitmen terhadap guide inquiry ilmiah. Dengan demkian, dalam pendekatan scientific dengan model Guide inquiry siswa tidak hanya dituntut agar menguasai materi pelajaran, akan tetapi bagaimana mereka dapat menggunakan kemampuan yang dimilikinya secara optimal.

\section{METODE}

Penelitian tindakan sekolah ini dilaksanakan di ruang Kelas VIII B SMP Negeri 1 Besuki Tulungagung. pada semester 2, pada tanggal 9 April 2016 sampai dengan 16 April 2016. Dalam penelitian ini subjek yang digunakan adalah seluruh siswa Kelas VIII B SMP Negeri 1 Besuki Tulungagung tahun pelajaran 2015/2016 sebanyak 26 siswa terdiri dari 9 orang siswa laki-laki dan 17 orang siswa perempuan dengan memiliki latar belakang sosial ekonomi, prestasi akademik yang cukup variatif.

Penelitian ini dilakukan dengan dua siklus, dimana masing-masing siklus dikenai perlakuan yang sejenis dengan bobot yang beda. Dibuat dua siklus dimaksudkan untuk memperbaiki system pengajaran yang dilaksanakan.

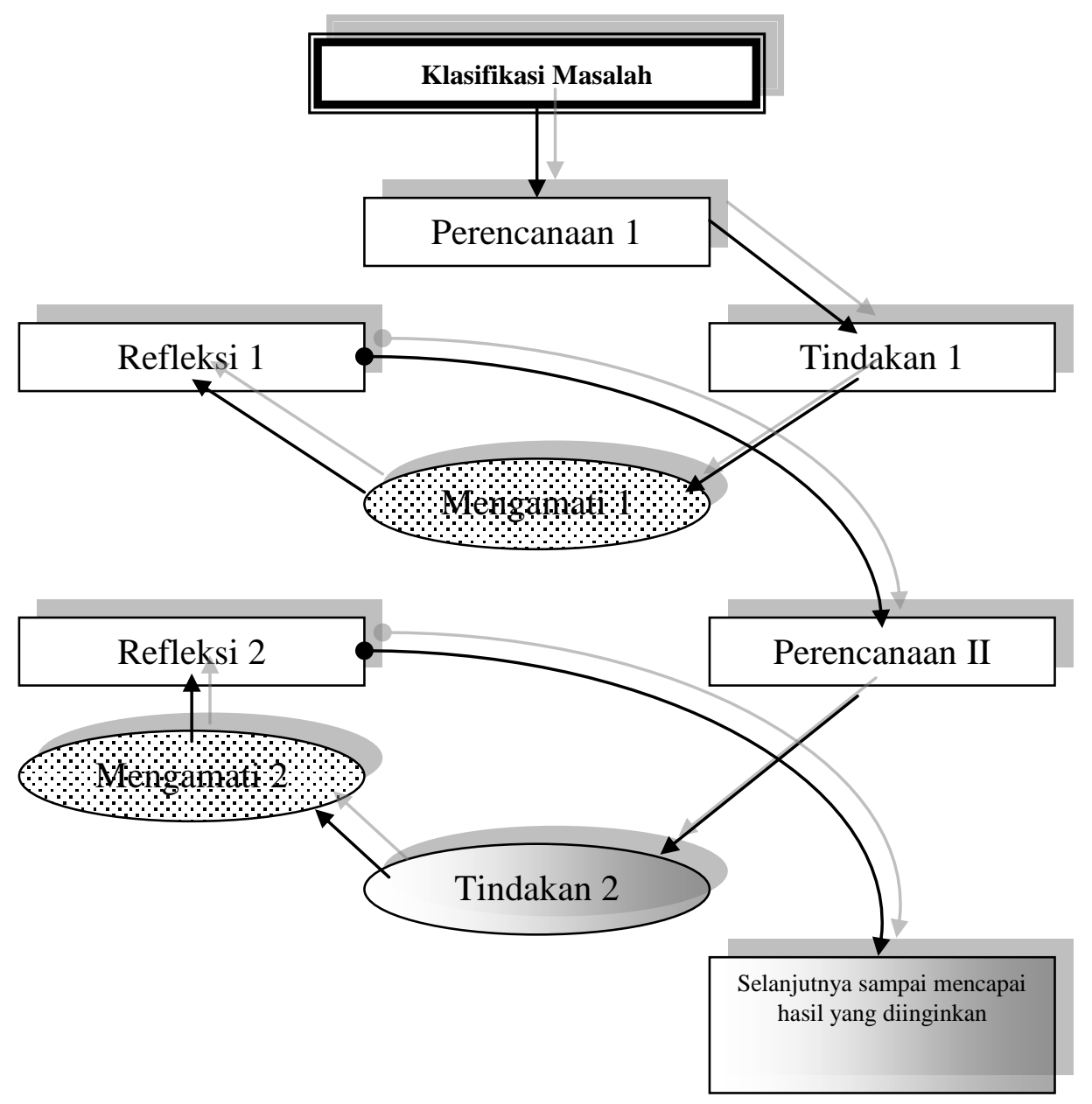

Gambar 1 Langkah-Langkah PTK dengan 2 Siklus

Adapaun ragam instrument penelitian tindakan kelas yang telah dipersiapkan yaitu, Rencana Pelaksaaan Pembelajaran sebagai instrument rencana 
pelaksanaan tindakan. Lembar observasi Guru sebagai instrument utama pengumpul data proses dan lembar observasi siswa, wawancara, angket dan catatan lapangan sebagai instrument pendukung pengumpul data proses. Selain itu juga terdapat instrument pengumpul data hasil, yang dapat dikumpulkan dari hasil belajar berdasarkan soal-soal yang diberikan, serta ketrampilan siswa berdasarkan rubrik yang ada.

Teknik analisis yang digunakan yaitu deskriptif persentase. Data hasil penelitian yang dianalisis meliputi rata-rata kelas, ketuntasan belajar individu dan ketuntasan belajar secara klasikal. Selanjutnya hasil analisis data diperoleh baik secara kualitatif (dengan kata-kata) dan kuantitatif (dengan grafik). Hasil ini diinterprestasikan dan disimpulkan untuk menjawab permasalahan yang ada. Analisis data dari sumber-sumber informasi hasil penelitian di dapat dari: (1) Analisis dara observasi, (2) analisis data wawancara, dan 3) analisis data tes.

\section{HASIL}

\section{Siklus I}

Dalam pelaksanaan pembelajaran, Guru masih menghadapi berbagai kendala, antara lain: (1) Masih ada kelompok yang bingung dalam mengikuti langkah-langkah yang tertera dalam lembar kegiatan. (2) Masih ada beberapa siswa yang belum aktif dalam pelaksanaan percobaan. 3) Ketika pelaksanaan diskusi, ada beberapa siswa yang tidak aktif menyampaikan pendapatnya. (4) Dalam menyimpulkan hasil percobaan, terdapat 3 (tiga) kelompok yang malu untuk presentasi, dan hanya terdapat 3 (tiga) siswa yang mengajukan pertanyaan.

Adapun prosentase hasil observasi dalam pelaksanaan percobaan pada siklus I dapat dilihat dari tabel 3 bawah ini. Perhitungan prosentase keberhasilan siklus I di bawah ini diskusikan juga dengan teman sejawat.

Tabel 1 Prosentase Hasil Observasi Siklus I

\begin{tabular}{|l|l|l|}
\hline No & Kegiatan Siswa & Prosentase \\
\hline 1 & Kelengkapan menyiapkan alat dan bahan percobaan & $40 \%$ \\
\hline 2 & $\begin{array}{l}\text { Keruntutan langkah-langkah dalam pelaksanaan kegiatan } \\
\text { percobaan }\end{array}$ & $55 \%$ \\
\hline 3 & Keaktifan siswa selama melaksanakan kegiatan percobaan & $60 \%$ \\
\hline 4 & Keaktifan siswa dalam mengutarakan pendapat saat berdiskusi & $60 \%$ \\
\hline 5 & Kesimpulan akhir sesuai percobaan & $54 \%$ \\
\hline
\end{tabular}

Hasil post test pada siklus pertama dapat menjadi perhitungan persentase peningkatan prestasi belajar siswa. Dengan acuan penilaian tetap berdasarkan nilai KKM yang telah ditetapkan yaitu paling sedikit siswa memperoleh nilai 70 . Adapun rekapitulasi hasil test siklus I adalah sebagai berikut:

Tabel 2 Hasil Post Test Siklus Pertama

\begin{tabular}{|l|l|l|}
\hline No & Deskripsi & Nilai \\
\hline 1 & Jumlah Nilai & 1730 \\
\hline 2 & Rata-rata Hasil Post Test & 66,5 \\
\hline 3 & Jumlah siswa yang mendapat nilai diatas KKM (70) & 10 \\
\hline 4 & Presentase siswa yang mendapat nilai diatas KKM (70) & $38,5 \%$ \\
\hline 5 & Jumlah siswa yang mendapat nilai dibawah KKM (70 & 16 \\
\hline
\end{tabular}




\begin{tabular}{|l|l|l|}
\hline 6 & Presentase siswa yang mendapat nilai dibawah KKM (70) & $59,4 \%$ \\
\hline
\end{tabular}

Nilai rata-rata hasil post test, dapat dihitung dari :

$\dot{X}=\frac{\sum X}{\sum N}$, Jadi $\dot{X}=\frac{1730}{26}=66,5$

Nilai $\mathrm{KKM}=70$. Jadi sudah ada peningkatan prestasi belajar, namun hanya

sedikit.

Rumus Ketuntasan Individu (prestasi belajar siswa) $=$

$\frac{\sum \text { siswa yang mendapat nilai } \geq 70}{\sum \text { siswa }} \times 100 \%$

Jadi, Ketuntasan Individu (prestasi belajar siswa) $=\frac{10}{26} \times 100 \%=38,5 \%$

Masing kurang dari indicator pencapaian siklus I sebesar $85 \%$ atau lebih.

Maka dilanjutkan percobaan pembelajaran dengan Pendekatan scientific dengan model Guide inquiry pada siklus II.

Tabel berikut adalah daftar frekuensi nilai post test siklus I Bahasa Inggris Vocabulary teks descritive dengan soal pengerjaan siswa Kelas VIII B SMP Negeri 1 Besuki Tulungagung setelah pembelajaran menggunakan Pendekatan scientific dengan model Guide inquiry, dengan nilai minimal KKM sebesar 70:

Tabel 3 Daftar Nilai Ulangan Harian Siklus I

\begin{tabular}{|l|l|l|}
\hline Nilai & Frekuensi & Prosentase \\
\hline $0-40$ & 3 & $9,4 \%$ \\
\hline $41-69$ & 13 & $50,0 \%$ \\
\hline $70-100$ & 10 & $38,5 \%$ \\
\hline Jumlah & 26 & $100 \%$ \\
\hline
\end{tabular}

Dari tabel diatas dapat kita lihat terdapat 3 siswa atau 9,4\% yang mendapat nilai $0-40,13$ siswa atau 50,0\% yang mendapat nilai antara $41-69$, dan 10 siswa atau $38,5 \%$ yang mendapat nilai antara $70-100$. Dengan ketentuan nilai KKM 70, dapat disimpulkan jika pencapaian prestasi nilai $70-100$, maka prestasi belajar siswa telah meningkat dari 3,85\% menjadi 38,5\%. Namun karena belum mencapai target indicator pencapaian siklus I sebesar $85 \%$ atau lebih, maka akan dilanjutkan ke Siklus II.

Selain itu, dari proses wawancara diperoleh kesimpulan bahwa beberapa siswa menjadi bersemangat dalam belajar Bahasa Inggris, karena pelaksanaan kegiatan belajar Bahasa Inggris dengan Pendekatan scientific dengan model Guide inquiry ini dilaksanakan dengan langsung secara mandiri oleh siswa, dan melaksanakan kegiatan bersama kelompok sehingga lebih ringan. Meskipun masih terdapat kendala-kendala seperti yang telah diuraikan dalam laporan observasi.

\section{Siklus II}

Dalam pelaksanaan proses pembelajaran, Guru telah melaksanakan perbaikan dari siklus I, siswa sudah mengalami kemajuan dan pelaksanaan-pun telah berjalan baik. Namun Guru menemukan masalah baru dalam pelaksanaan siklus II, yaitu: (1) Suasana gaduh di kelas, karena beberapa siswa menjadi saling 
berteriak satu sama lain. Namun diantisipasi oleh peneliti dengan memerintahkan ketua kelompok untuk mengkondisikan anggotanya. (2) Masih terdapat 3-4 siswa yang malu dalam presentasi dan kurang aktif dalam diskusi kelompok.

Adapun prosentase hasil observasi dalam pelaksanaan percobaan pada siklus II dapat dilihat dari tabel bawah ini. Perhitungan prosentase keberhasilan siklus II di bawah ini diskusikan juga dengan teman sejawat.

Tabel 4 Prosentase Hasil Observasi Siklus II

\begin{tabular}{|l|l|l|}
\hline No & Kegiatan Siswa & Prosentase \\
\hline 1 & Kelengkapan menyiapkan alat dan bahan percobaan & $80 \%$ \\
\hline 2 & $\begin{array}{l}\text { Keruntutan langkah-langkah dalam pelaksanaan kegiatan } \\
\text { percobaan }\end{array}$ & $90 \%$ \\
\hline 3 & Keaktifan siswa selama melaksanakan kegiatan percobaan & $85 \%$ \\
\hline 4 & Keaktifan siswa dalam mengutarakan pendapat saat berdiskusi & $92 \%$ \\
\hline 5 & Kesimpulan akhir sesuai percobaan & $89 \%$ \\
\hline
\end{tabular}

Hasil post test pada siklus kedua dapat menjadi perhitungan persentase peningkatan prestasi belajar siswa. Dengan acuan penilaian tetap berdasarkan nilai KKM yang telah ditetapkan yaitu paling sedikit siswa memperoleh nilai 70 . Adapun rekapitulasi hasil test siklus II adalah sebagai berikut:

Tabel 5 Hasil Post Test Siklus Kedua

\begin{tabular}{|l|l|l|}
\hline No & Deskripsi & Nilai \\
\hline 1 & Jumlah Nilai & 2115 \\
\hline 2 & Rata-rata Hasil Post Test & 81,3 \\
\hline 3 & Jumlah siswa yang mendapat nilai diatas KKM (70) & 23 \\
\hline 4 & Presentase siswa yang mendapat nilai diatas KKM (70) & $88,5 \%$ \\
\hline 5 & Jumlah siswa yang mendapat nilai dibawah KKM (70 & 3 \\
\hline 6 & Presentase siswa yang mendapat nilai dibawah KKM (70) & $11,5 \%$ \\
\hline
\end{tabular}

Nilai rata-rata hasil post test, dapat dihitung dari :

$\dot{X}=\frac{\sum X}{\sum N}$, Jadi $\dot{X}=\frac{2115}{26}=81,3$

Nilai $\mathrm{KKM}=70$. Jadi sudah ada peningkatan prestasi belajar yang signifikan.

Rumus Ketuntasan Individu (prestasi belajar siswa) $=$

$\frac{\sum \text { siswa yang mendapat nilai } \geq 70}{\sum \text { siswa }} \times 100 \%$

Jadi, Ketuntasan Individu (prestasi belajar siswa) $=\frac{23}{26} \times 100 \%=88,5 \%$

Telah mencapai indicator pencapaian siklus II sebesar $85 \%$ atau lebih.

Maka tidak perlu dilanjutkan percobaan pembelajaran dengan Pendekatan scientific dengan model Guide inquiry pada siklus III.

Tabel berikut adalah daftar frekuensi nilai post test siklus II Bahasa Inggris dengan Vocabulary teks descritive siswa Kelas VIII B SMP Negeri 1 Besuki Tulungagung setelah pembelajaran menggunakan Pendekatan scientific dengan model Guide inquiry siklus II, dengan nilai minimal KKM sebesar 70: 
Tabel 6 Daftar Nilai Ulangan Harian Siklus II

\begin{tabular}{|l|l|l|}
\hline Nilai & Frekuensi & Prosentase \\
\hline $0-40$ & 0 & $0,0 \%$ \\
\hline $41-69$ & 3 & $11,5 \%$ \\
\hline $70-100$ & 23 & $88,5 \%$ \\
\hline Jumlah & 26 & $100 \%$ \\
\hline
\end{tabular}

Dari tabel diatas dapat kita lihat terdapat 3 siswa atau $11,5 \%$ yang mendapat nilai antara $41-69$, dan 23 siswa atau 88,5\% yang mendapat nilai antara 70 - 100. Dengan ketentuan nilai KKM 70, dapat disimpulkan jika pencapaian prestasi nilai $70-100$, maka prestasi belajar siswa telah meningkat dari $38,5 \%$ menjadi $88,5 \%$. Dengan $88,5 \%$ maka telah tercapai indicator pencapaian siklus II sebesar yang $85 \%$ atau lebih, maka tidak perlu dilanjutkan ke Siklus III.

Selain itu, dari proses wawancara diperoleh kesimpulan bahwa beberapa siswa menjadi bersemangat dalam belajar Bahasa Inggris, karena pelaksanaan kegiatan belajar Bahasa Inggris yang berpendekatan scientific dengan model Guide inquiry ini dilaksanakan dengan secara baik bersama kelompok menjadikan mereka lebih rileks dan ringan dalam mengerjakan laporan kegiatan. Meskipun masih terdapat kendala-kendala seperti yang telah diuraikan dalam laporan observasi.

\section{PEMBAHASAN}

Berdasarkan hasil pelaksanaan pada siklus I, II dapat dinyatakan bahwa terjadi peningkatan kualitas pembelajaran yang tampak dan perolehan hasil evaluasi dan keaktifan siswa. Dari tabel 4.2 dan gambar 4.2 siklus I hasil observasi menunjukkan, prosentase keberhasilan kelengkapan menyiapkan alat dan bahan percobaan $40 \%$, prosentase keruntutan langkah-langkah yang ditempuh dalam pelaksanaan percobaan $55 \%$, prosentase keaktifan siswa dalam melaksanakan kegiatan percobaan $60 \%$, prosentase keaktifan siswa dalam mengutarakan pendapat saat berdiskusi $54 \%$ dan prosentase hasil penarikan kesimpulan akhir sesuai percobaan $50 \%$.

Berdasarkan tabel 4.5 dan gambar 4.5 siklus II hasil observasi menunjukkan, prosentase keberhasilan metode kelengkapan menyiapkan alat dan bahan percobaan siswa yang disiapkan $80 \%$, prosentase keruntutan langkahlangkah yang ditempuh dalam pelaksanaan percobaan $90 \%$, prosentase keaktifan siswa dalam melaksanakan kegiatan percobaan $85 \%$, prosentase keaktifan siswa dalam mengutarakan pendapat saat berdiskusi $92 \%$ dan prosentase hasil penarikan kesimpulan akhir sesuai percobaan $89 \%$.

Dari daftar nilai (lihat lampiran) dapat kita lihat adanya prosentase kenaikan nilai Bahasa Inggris mulai dari kondisi awal pra tindakan, diketahui baru 1 siswa atau 3,85\% yang mengalami ketuntasan belajar dan mendapatkan nilai sesuai dengan KKM. Hasil evaluasi siklus I menunjukkan baru 10 siswa atau $38,5 \%$ yang mengalami ketuntasan belajar dan mendapat nilai sama dengan atau di atas KKM yaitu 70. Hal itu menunjukkan bahwa pelaksanaan siklus I belum mencapai keberhasilan, karena indicator pencapaian adalah sebesar $85 \%$ atau lebih. Siklus II menunjukkan ada 23 siswa atau 88,5\% dari 26 siswa yang mengalami ketuntasan belajar. Sehingga peneliti menyimpulkan bahwa pada 
siklus II ini peneliti telah mencapai keberhasilan dari penelitian tindakan kelas yang telah dilakukan.

Ketika peneliti melaksanakan siklus I, peneliti mengalami berbagai kendala antara lain Sebagian besar siswa masih ragu-ragu saat diminta menuliskan kosa kata yang telah dipelajarinya dalam bentuk kalimat sederhana. Masih ada kelompok yang bingung dalam mengikuti langkah-langkah yang tertera dalam lembar kegiatan. Masih ada beberapa siswa yang belum aktif dalam pelaksanaan percobaan. Ketika pelaksanaan diskusi, ada beberapa siswa yang tidak aktif menyampaikan pendapatnya. Dalam menyimpulkan hasil percobaan, terdapat 3 (tiga) kelompok yang malu untuk presentasi, dan hanya terdapat 3 (tiga) siswa yang mengajukan pertanyaan.

Peneliti kemudian melaksanakan siklus II sebagai perbaikan siklus I, sebelum pelaksanaan siklus II ini peneliti mengganti rencana pembelajaran Pendekatan scientific dengan model Guide inquiry baru yaitu dengan mengerjakan vocabulary menggunakan media tabel deskripsi hewan dan atau gambar agar menguasai isi teks descriptive tentang hewan dalam bahasa Inggris.. Dalam pelaksanaan percobaan, peneliti senantiasa memberi bimbingan untuk siswanya dalam melaksanakan langkah-langkah sesuai lembar kegiatan. Peneliti pun memberi bimbingan siswa saat berdiskusi untuk menarik kesimpulan. Dengan adanya motivasi guru berupa reward, siswa telah terlihat aktif dalam kegiatan pembelajaran dalam melaksanakan percobaan, presentasi di depan kelas dan berdiskusi menarik kesimpulan. Meskipun ada kendala yaitu suasana gaduh di kelas, karena beberapa siswa menjadi saling berteriak satu sama lain., namun dengan hasil prestasi belajar yang dicapai dapat disimpulkan bahwa penelitian tindakan kelas dari siklus II ini telah berhasil.

\section{KESIMPULAN}

Berdasarkan hasil penelitian tindakan kelas yang telah dilaksanakan dalam 2 siklus dengan menerapkan Pendekatan scientific dengan model Guide inquiry dalam pembelajaran Bahasa Inggris pada siswa Kelas VIII B SMP Negeri 1 Besuki Tulungagung, dapat dibuat kesimpulan sebagai berikut : Penerapan pendekatan scientific dengan model Guide inquiry dapat meningkatkan prestasi belajar Bahasa Inggris siswa Kelas VIII B SMP Negeri 1 Besuki Tulungagung. Berdasarkan hasil observasi dan pelaksanaan siklus I dan II juga dapat kita amati adanya perubahan kenaikan prosentase dalam menyiapkan alat dan bahan, keruntutan langkah-langkah siswa dalam melaksanakan percobaan, keaktifan siswa dalam melaksanakan kegiatan percobaan, keaktifan siswa ketika berdiskusi dan hasil akhir atau simpulan yang diperoleh dari hasil kegiatan diskusi.

\section{SARAN}

Berdasarkan hasil penelitian, maka ada beberapa saran yang dapat dipergunakan sebagai bahan pertimbangan dan sebagai bahan uraian penutup penelitian tindakan kelas ini, antara lain: (1) Bagi Guru, Hendaknya mempersiapkan secara cermat perangkat pendukung pembelajaran dan fasilitas belajar yang diperlukan, karena sangat mempengaruhi efektivitas dan efisiensi pembelajaran yang pada akhirnya berpengaruh pada proses dan prestasi belajar Bahasa Inggris siswa. (2) Bagi Siswa, Hendaknya ikut berperan aktif dalam proses pembelajaran, selalu mengerjakan tugas-tugas yang diberikan guru dan 
meningkatkan usaha belajar sehingga dapat memperoleh prestasi yang diharapkan. (3) Bagi Sekolah, Hendaknya mengupayakan pengadaan berbagai media pembelajaran Matematika untuk kelas.

\section{DAFTAR RUJUKAN}

Harmer, J. 1991. The Practice of English Language Teaching. Essex: Longman Ibrahim, I. 2007. Pembelajaran Ikuiri. (Online), (http://kpicenter.org/index.php?option=com_content\&task=view\&id=37\&Itemid=4), diakses 5 September 2007.

Schmidth, M.K. dkk. 2009. Teori Pembelajaran dan Pengajaran. Yogyakarta: Mirza Media 